\title{
Two form-genera of aerophytic heterocytous cyanobacteria from Brasilian rainy forest „Mata Atlântica”
}

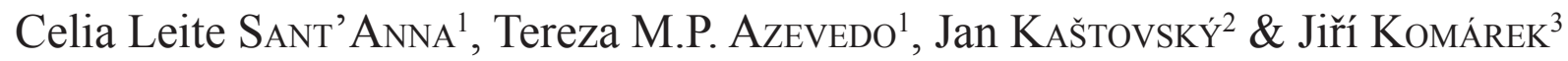 \\ ${ }^{1}$ Institute of Botany, Section of Phycology,, Caixa postal 4005, BR-01051, São Paulo, SP, Brazil \\ ${ }^{2}$ Faculty of Science, University of South Bohemia, Branišovská 31,CZ-37005 České Budĕjovice, Czech \\ Republic \\ ${ }^{3}$ Institute of Botany, AS CR Dukelská 135, CZ-379 01 Třeboň, Czech Republic
}

\begin{abstract}
Two specific and characteristic morphotypes of the cyanobacterial heterocytous and heteropolar genera from the family Microchaetaceae were recognized in subaerophytic, epiphytic, epidendric and soil habitats in Brasilian rainy forest "Mata Atlântica". The modern taxonomy of cyanobacteria is based mainly on molecular sequencing; the both new types were not yet cultured and their genetic relations must be solved in future. However, they can not be included in any generic unit supported by genetic methods and correspond morphologically to quite special and phenotypically yet unknown generic entities. Therefore, new form-genera Ophiothrix and Streptostemon are described. Few subtypes, which can be designated as new species according to traditional cyanobacterial taxonomy, were recognised from both these genera. Another tropical cyanobacterium "Scytonema hansgirgii Schmidle", described from the similar habitat (bark of trees) in Indonesia and central Africa, belongs evidently also to the genus Ophiothrix.
\end{abstract}

Key words: cyanobacteria, Ophiothrix, Streptostemon, new genera, tropical forests

\section{Introduction}

Two morphotypes of filamentous, heterocytous and heteropolar cyanobacteria without terminal hairs, which belong evidently to the family Microchaetaceae according to polarized filaments and morphological structure were found during the investigation of cyanobacterial microflora of the tropical rainy forest „Mata Atlântica” along the SE Atlantic coast of Brazil. Both the types do not correspond to any from known cyanobaterial generic entity. The cultivation of them was not successful up to now and they were therefore not analysed yet by molecular methods. However, their biological and phenotypic specificity is quite unique (cf. GeItLer 1932, 1942; BouRrelly 1970) and differs from all described genera, even those confirmed by molecular investigation (HOFFMANN et al. 2005, etc.). The substantial disagreement with other microchaetacean and scytonematacean genera determined by molecular sequencing (Fiore et al. 2007: Brasilonema; Flechtner et al. 2002: Spirirestis; CASAMATTA et al. 2006: Rexia; cf. Fig. 1) which are also clearly delimited by morphological markers, justifies the description of new generic units.

Our new described types were repeatedly found and studied in aerophytic habitats of tropical forest "Mata Atlântica". They are characterized by phenotypic markers, which were found important for genetically supported genera of Microchaetaceae (Spirirestis, Rexia, Tolypothrix), but which do not correspond to any known generic unit. Both types should be therefore considered as a special form-genera, which should be confirmed by molecular methods in future. They colonize a special niche in nature in Brazilian coastal rainy forest and we describe these generic entities (Ophiothrix, Streptostemon) therefore as a starting point for their future investigation. The definition of new cyanobacterial genera on the basis of revised phenotypic generic features was successful already in other filamentous families, and all such genera were later confirmed by molecular criteria (Leptolyngbya, Arthrospira, Tychonema, Planktothrix and numerous others; cf. Castenholz 2001). The justification of our new genera is therefore expectable. 


\section{Material and methods}

Samples were collected in the part of Atlantic rainy forest "Mata Atlantica", northern and NE from São Paulo (State São Paulo), particularly in the vicinity of towns Paranapiacaba, Ubatuba and Jureia. Because the samples were mostly from aerophytic (epiphytic on trees, on old woods and in soils) localities, they were preserved in a dried state.

The study of natural populations was carried out by standard methods, optical microscopy, fluorescence microscopy and at highest possibly magnification by help of the microscopes Olympus BX51 and Leitz Dialux 22. The specimens were documented by drawing and microphotos techniques. All types were also cultivated in BG 11 solid media, but their continual cultivation was not successful. This material was used for the study of morphology, but it was not possible for molecular analyses.

Both genera are therefore studied and described according to the principles of botanical nomenclatural rules (Greuter et al. 2000).

\section{Results}

\section{The genus Ophiothrix}

Description: Filaments solitary or few parallel situated in small groups, thick (over $10 \mu \mathrm{m}$ wide), creeping on the substrate (on mosses, aquatic plants or aerophytic on bark of trees), flexuous, heteropolar or seemingly isopolar, enveloped by thin, firm, sometimes slightly lamellated sheaths; the sheath is closed at the apex or open after hormogonia liberation. Filaments are simple, with rare false branching of coleodesmoid type, maximally two joined parallel together; the branches grow after separation from the mother trichome \pm parallel to the mother filament. Trichomes strictly cylindrical along the whole length, not attenuated towards ends, not constricted at cross-walls. Cells cylindrical, always shorter than wide, bluegreen, pale blue-green, olive-green, yellowish or violet; apical cells widely rounded, without calyptra. Heterocytes basal, solitary, arise on the basis of young filaments and young branches, usually hemispherical; occasionally develop barrel-shaped or cylindrical intercalary, solitary heterocytes. Akinetes not known. Reproduction by hormogonia, separation of false branches and by fragmentation of filaments. - Type species: Ophiothrix epidendron spec. nova. List of species see on Table 1.
Diagnosis: Fila solitaria vel paucim paralleliter aggregata, irregulariter flexuousa, repentia, cylindrica, plus quam 10 mm lata, rarissime false ramosa; rami breves, longitudine ad fila materna \pm paralleliter conjuncta, apice rotundata; hormogonia heteropolares. Vaginae firmae, cylindricae, tenues, incolores, interdum paucim lamellosae, ambitu plus minusve inaequales, mucilaginosae, apice clausae, postea hormogonia formantur apertae. Trichomata cylindrica, ad septa haud vel paucim constricta, ad apices not attenuata. Cellulae cylindricae, semper brevior quam latae, contentu plus minusve homogeneo, aeruginoso olivaceo vel violaceo; cellulae apicales rotundatae sine calyptra. Heterocytae in hormogoniis primum basales, solitariae, hemisphaeriaceae, cum porum unum, postere etiam intercalares, \pm cylindricae, solitariae, cum poris binis, plus minusve isodiamtericae vel longior vel brevior quam latae. Akinetes carentes. Reproductio hormogoniis vel trichomatibus fragmentatione. - Typus generis: Ophiothrix epidendron sp. nov.

\section{List of species:}

\section{Ophiothrix epidendron sp. nov. (Figs 2,5)}

Filaments solitary, rarely parallely two together, creeping on mosses on bark of trees (subaerophytically), not or rarely with solitary tolypotrichoid (or coleodesmioid) false branches, flexuous, 12-13 $\mu \mathrm{m}$ wide. Sheaths attached to trichomes, colourless, brownish with age, not or slightly lamellated, closed or open at the ends. Trichomes not constricted at cross-walls, not attenuated towards ends, 10-12 $\mu \mathrm{m}$ wide. Cells olive-green, sometimes slightly brownish or violet, very short; terminal cells sometimes yellowish, widely rounded, without calyptra. Habitat: On mosses and liverworths on bark of trees (Sapium sp.) in tropical forest Mata Atlântica; near Paranapiacaba SP, Brasil.

Diagnosis: Fila solitaria, paucim dua paralleliter consociata, flexuosa, ad substratum repentes, 12 $13 \mu \mathrm{m}$ lata. Vaginae tenues, incolores, despues fuscae, non vel paucim lamellosae. Trichomata ad septa haud constricta, ad apices not attenuata, 10-12 4 m lata. Cellulae curtae, olivaceo-virides, fuscescentes vel paucim violaceae; cellulae terminales lutescentes, rotundatae, sine calyptra. - Habitatio: Ad muscis hepaticisque epidendris 


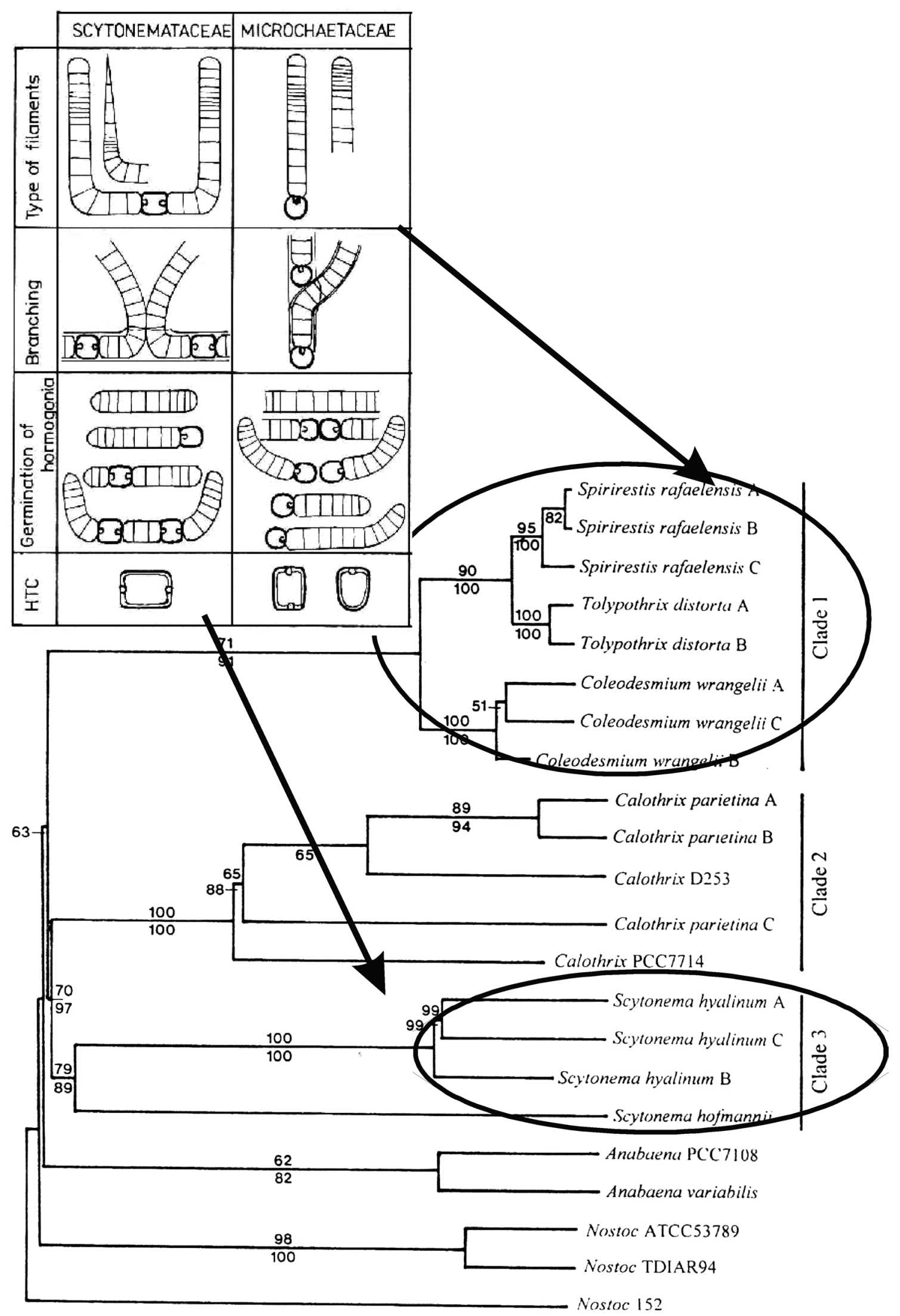

Fig. 1. Scheme of generic characters of Microchaetaceae and Scytonemataceae (from KomÁReK \& ANAgnostidis 1989); the phylogenetic tree from FLECHTNER et al. (2002). 
(Sapium sp.) serpentes, in silvis tropicalibus; locus classicus: apud oppidem Paranapiacaba, Brasilia (São Paulo). - Typus (holotypus): Exsiccatum SP 400881; dep. in herbarium (SP) Institute of Botany, SP, Brazil.

\section{Ophiothrix epibryos (KOMÁREK) comb. nov. (Fig. 3)}

Basionym: Camptylonemopsis epibryos Komárek, Preslia 75: 224, 2003.

Filaments solitary, irregularly wavy, creeping on the surface of submersed mosses (Fissidens cf. asplenioides) and rests of plants, cylindrical along the whole length, 15-16.5 $\mu \mathrm{m}$ wide, very rarely falsely (coleodesmioid) branched; branches parallel situated to the mother filaments. Sheaths attached to the trichomes, thick, lamellated, colourless, closed at the ends. Trichomes cylindrical, not constricted at cross-walls, 11$14 \mu \mathrm{m}$ wide. Cells always shorter than wide, violet; apical cells widely rounded, without calyptra. Heterocytes mostly intercalar, solitary, cylindrical, secondary basal, \pm isodiametric, \pm so wide like vegetative cells. - Habitat: Creeping on submersed substrates (mostly mosses and plants) in acidic, not polluted pools ("restingas") near coast of SE Brazil, near the edge of tropical forest; near Ubatuba, SP, Brasil.

Ophiothrix hansgirgii (SCHMIDLE) comb. nov. (Fig. 4)

Basionym: Scytonema hansgirgii Schmidle, Allg. Bot. Ztschr. 1900: 78, 1900; sec. Hedwigia 39: 189, 1900.

Blackish layer (spots) on the bark of trees in tropical forests. Filaments short, disintegrating, irregular, flexuous, wrinkled, creeping, partly with erect ends, only sporadically false branched (very rarely also in twos), 12-18 $\mu \mathrm{m}$ wide, sometimes circular bent. Sheaths 1-2 $\mu \mathrm{m}$ thick, yellowbrown, lamellated. Trichomes not constricted at cross-walls, 14-16 $\mu \mathrm{m}$ wide. Cells short, 4-8× shorter than wide, blue-green; terminal cells a little larger, hemispherical, rounded, often yellowish coloured. Heterocytes short, rounded, of the same width like vegetative cells. - Habitat: On bark of trees; known from E India (near Poona) and central (equatorial) Africa (Duvigneaud \& Symoens 1949).

\section{The genus Streptostemon}

Description: Filaments firstly polarized with basal heterocytes, later joined many together into the tight and densely arranged fascicles, up to over $1 \mathrm{~mm}$ long; they are firstly creeping, later \pm erect and usually forming small tufts with \pm parallel situated trichomes, heteropolar, \pm cylindrical, sometimes slightly widened at the basis and slightly widened or narrowed at the apex, without hairs, without branches, quite extraordinary only with scytonematoid false branching, usually with basal heterocytes. Sheaths thin, firm, lamellated, colourless or yellowish, open at the apex. Trichomes cylindrical or slightly narrowed in the middle part and slightly widened at the basis and at the apex, 3-6 $\mu \mathrm{m}$ wide, not constricted at cross-walls, with basal and less frequently also intercalary heterocytes. Cells cylindrical, isodiametric or slightly shorter or longer than wide, olive-green, greyish blue-green or yellowish; apical cells rounded or spherical and \pm hyaline. Basal heterocytes subspherical, hemispherical, oval or oval-cylindrical, intercalar heterocytes cylindrical, usually distinctly longer than wide. Akinetes not known. Reproduction by hormogonia. - Type species: Streptostemon capitatus sp. nov.

Diagnosis: Fila heteropolares, cylindricae, cum heterocytis basalibus, iuvenilia partim repentes, despues multis in fasciculis densis, plus quam $1 \mathrm{~mm}$ longis, erectis, plus minusve paralleliter conjunctae. Vaginae tenues, firmae, lamellosae, incolores vel lutescentes, ad apicum apertae. Trichomata cylindrica, interdum ad apices paucim dilatatae vel angustatae, sine pilis terminalibus, rarissime false ramosa, 3-6 $\mu m$ lata, ad dissepimenta non constricta, cum heterocytis basalibus intercalaribusque. Cellulae cylindricae, plus minusve isodiametricae vel paucim longior vel crassior quam latae, olivaceovirides, griseo-aeruginosae vel lutescentes; cellulae apicales rotundatae vel sphaericae, saepe hyalinae. Heterocytae basales subsphericae, hemisphaericae, ovales vel ovales-cylindricae, intercalares cylindricae, saepe distincte longior quam latae. Akinetes carentes. Reproductio hormogoniis. - Typus generis: Streptostemon capitatus sp. nov. 


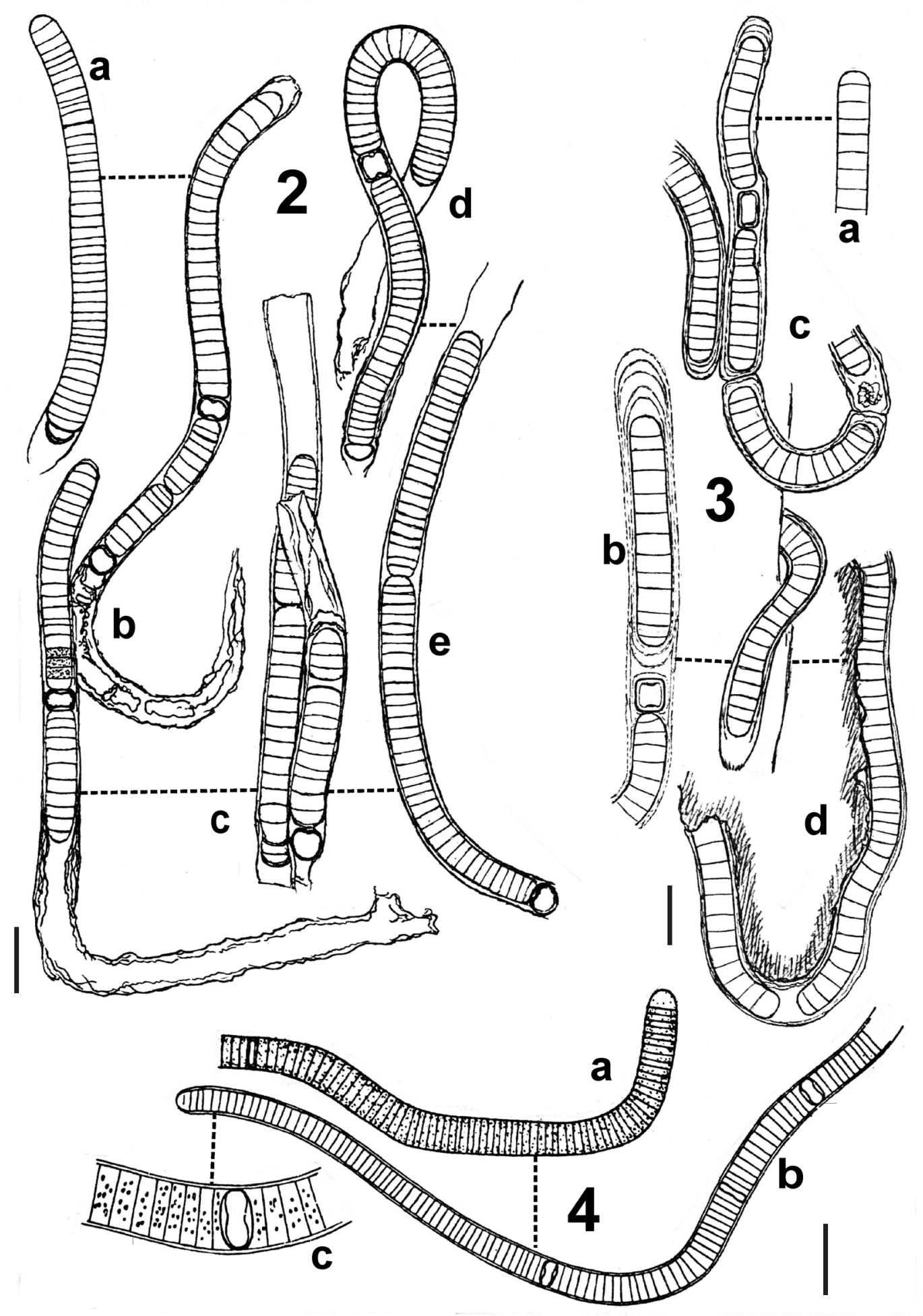

Figs 2-4. The species of the genus Ophiothrix: (2) Ophiothrix epidendron (orig.); (3) Ophiothrix epibryos (from KOMÁREK 2003); (4) Ophiothrix hansgirgii [(a) from Schmidle 1900; (b-c) from Duvigneaud \& Symoens (1949)]. Scale bar $20 \mu \mathrm{m}$. 
Table 1. Review of Ophiothrix species. The diacritical features are marked by black points.

\begin{tabular}{|c|c|c|c|}
\hline Ophiothrix & epidendron & epibryos & hansgirgii \\
\hline width of filaments $(\mu \mathrm{m})$ & $12-13$ & $15-16.5$ & $12-18$ \\
\hline width of trichomes $(\mu \mathrm{m})$ & $10-12$ & $11-14$ & $14-16$ \\
\hline form of sheaths & thin, firm, slightly lamellated & thick, lamellated & $\begin{array}{l}\text { thin }(1-2 \mu \mathrm{m} \text { wide }) \text {, } \\
\text { lamellated }\end{array}$ \\
\hline colour of sheaths & brownish & colourless & yellow-brown \\
\hline colour of cell content & $\begin{array}{l}\text { olive-green, rarely } \bullet \\
\text { slightly brownish or violet }\end{array}$ & reddish & blue-green \\
\hline $\begin{array}{l}\text { length of cells } \\
(\mu \mathrm{m})\end{array}$ & always shorter than wide & $3-10$ & 4-8 $\times$ shorter than wide \\
\hline $\begin{array}{l}\text { heterocytes } \\
(\mu \mathrm{m})\end{array}$ & $\begin{array}{l}\text { shortly barrel-shaped to } \\
\text { cylindrical, basal } \pm \text { conical- } \\
\text { rounded }\end{array}$ & $\begin{array}{l} \pm \text { cylindrical } \\
(10) 11-17 \times 10-14\end{array}$ & $\begin{array}{l}\text { rounded, } \\
\pm \text { isodiametrical }\end{array}$ \\
\hline ecology & $\begin{array}{l}\text { aerophytic, epiphytic on } \\
\text { corticolous mosses on bark } \\
\text { of Sapium sp. }\end{array}$ & $\begin{array}{l}\text { epiphytic on } \\
\text { submerged mosses in clear } \\
\text { acidic pools ("restingas") }\end{array}$ & on bark of trees \\
\hline distribution & $\begin{array}{l}\text { Atlantic Forest: } \\
\text { Paranapiacaba, SP, Brazil }\end{array}$ & $\begin{array}{l}\text { Atlantic Forest: Ubatuba, } \\
\text { SP, Brazil }\end{array}$ & $\begin{array}{l}\text { India, near Poona; secondary } \\
\text { in equatorial Africa }\end{array}$ \\
\hline
\end{tabular}

Table 2. Main differential phenotypic characters of the genera from the family Microchaetaceae.

\begin{tabular}{|c|c|c|c|c|c|}
\hline genus & $\begin{array}{l}\text { repeated } \\
\text { branching } \\
\text { (,dendroid } \\
\text { colonies“) }\end{array}$ & $\begin{array}{l}\text { cylindrical } \\
\text { vs. } \\
\text { narrowed } \\
\text { Tr in the } \\
\text { middle }\end{array}$ & $\begin{array}{l}\text { widened } \\
\text { ends }\end{array}$ & growth form & special characters \\
\hline Microchaete & - & cylindrical & $\begin{array}{c}- \\
\text { (or narrowed } \\
\text { ends) }\end{array}$ & creeping or erect & \\
\hline Camptylonemopsis & - & narrowed & $(+)$ & creeping, erect ends & \\
\hline Ophiothrix & - & $\begin{array}{l}\text { cylindrical } \\
\text { cylindrical }\end{array}$ & - & creeping (erect ends) & discoid cells \\
\hline Fortiea & - & $\begin{array}{l}\text { or narrowed } \\
\text { base }\end{array}$ & + & \pm erect & widened trichome ends \\
\hline Streptostemon & - & cylindrical & $(+)$ & erect fascicles & $\begin{array}{l}\text { fasciculated filaments } \\
\text { without branching }\end{array}$ \\
\hline Rexia & $(+)$ & cylindrical & - & \pm erect & cell division in two planes \\
\hline Spirirestis & + & $\begin{array}{l}\text { cylindrical } \\
\text { cylindrical }\end{array}$ & - & screw-like filaments & \\
\hline Tolypothrix & + & $\begin{array}{l}\text { or } \pm \\
\text { narrowed }\end{array}$ & $(+)$ & erect & \\
\hline Hassallia & + & cylindrical & - & \pm erect & discoid cells \\
\hline Coleodesmium & + & cylindrical & - & \pm erect & $\begin{array}{l}\text { fasciculated filaments with } \\
\text { branching }\end{array}$ \\
\hline
\end{tabular}



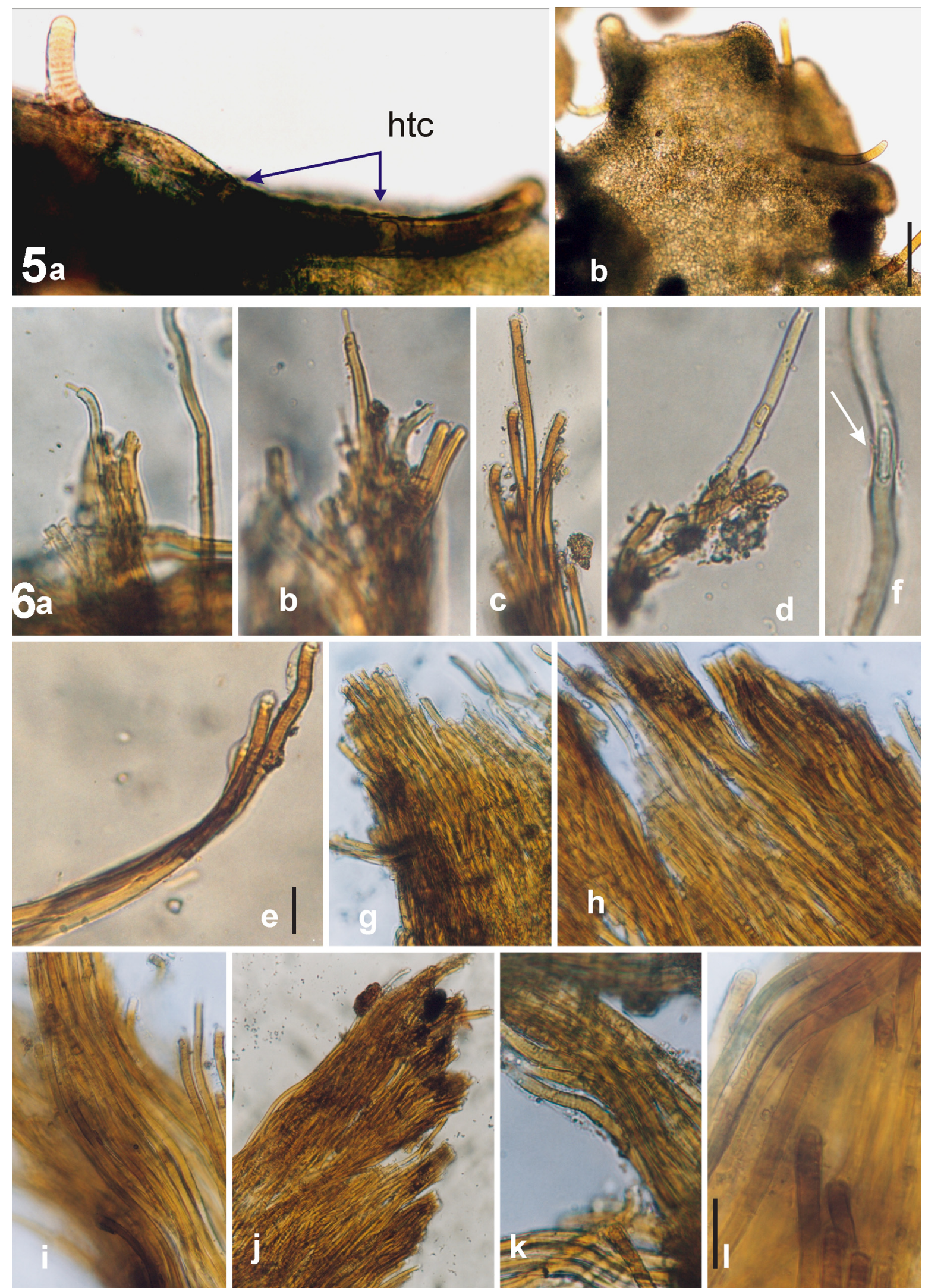

Fig. 5. Ophiothrix epidendron from original locality. Photos are selected from the samples from stems of Sapium sp. in tropical forest near Paranapiacaba (SP, Brazil).

Fig. 6. Streptostemon capitatus (orig. photo): (a-e) detail of filaments from the end of colonies; (f) detail of a long intercalar heterocyte; (g-k) details of the ends of colonies; (1) detail of arrangement of filaments in a colony. Photos are performed from natural material from lateritic soils in tropical forest near Paranapiacaba (SP, Brazil). Scale bar $20 \mu \mathrm{m}$. 
List of species:

\section{Streptostemon capitatus sp. nov. (Figs 6, 7)}

Many filaments joined \pm parallel into dense, rich fascicles; filaments $6-8 \mu \mathrm{m}$ wide, at the basis up to $11 \mu \mathrm{m}$ wide, \pm cylindrical, long. Sheaths distinct, slightly lamellated, yellowish. Trichomes \pm cylindrical, not constricted at cross-walls, sometimes very slightly widened, at the basis and towards ends, 4-6 $\mu \mathrm{m}$ wide, rarely narrowed up to $1.8 \mu \mathrm{m}$. Cells usually with slightly visible cross-walls, shorter than wide up to \pm isodiametric, pale greyish blue-green; apical cells spherical, \pm hyaline, sometimes with refractive content. Heterocytes basal, short, hemispherical, and intercalar, cylindrical, $8-11 \times 3.5-5 \mu \mathrm{m}$. Habitat: Blackish flat or tufty colonies on lateritic soils in tropical forest "Mata Atlântica"; near Paranapiacaba and São Paulo, SP, Brazil.

Diagnosis: Fila numerosa paralleliter in fasciculis dense conjuncta, 6-8 $\mu$ m lata, basim ad 11 um lata, plus minusve cylindrica, longa. Vaginae tenues, firmae, lutescentes, paucim lamellosae. Trichomata plus minusve cylindricae, ad dissepimenta non constricta, rarissime basim dilatata, despues et ad apices 4-6 4 m lata, rarissime attenuata ad $1.8 \mu \mathrm{m}$. Cellulae breviter quam latae ad plus minusve isodiametricae, pallide griseo-aeruginosae; cellulae apicales sphaericae, plus minusve hyalinae, interdum cum contentu hyalino, refractivo. Heterocytae basales breves, hemisphaericae, intercalares cylindricae, $8-11 \times 3.5-5 \mu \mathrm{m}$. - Habitatio: In tegetes nigrescentes, fasciculatis, in solis latericis in silvis tropicalibus; locus classicus: apud oppidem Paranapiacaba, Brasilia (São Paulo). Typus (holotypus): Exsiccatum SP 400882; dep. in herbarium (SP) Institute of Botany, SP, Brazil.

\section{Streptostemon lutescens sp. nov. (Fig 8)}

Many filaments \pm parallely and densely arranged in erect fascicles, cylindrical, long, $8-11 \mu \mathrm{m}$ wide, without branching. Sheaths distinct, colourless, sometimes slightly lamellated. Trichomes slightly widened at the apex, in the middle and to the basis sometimes indistinctly narrowed, in the upper part 5-6 $\mu \mathrm{m}$ wide, in narrow parts only $3 \mu \mathrm{m}$ wide, not constricted at cross-walls, only rarely indistinctly constricted at the ends and in hormogonia. Cells blue-green, olive-green to yellowish, \pm isodiametric, in meristematic zones and in hormogonia shorter than wide, in narrower parts cylindrical and up to $2 \times$ longer than wide; end cells widely rounded, sometimes more pale yellowish. Basal heterocytes ovoid, shortly barrel-shaped, hemispherical up to cylindricalrounded; intercalar heterocytes \pm cylindrical, 5-12 $\mu \mathrm{m}$ long. - Habitat: Subaerophytic on stones in tropical forests; near Jureia, SP, Brazil.

Diagnosis: Fila numerosa, plus minusve paralleliter dense in fasciculis erectis consociata, cylindrica, longa, 8-11 $\mu \mathrm{m}$ lata, sine ramificationibus. Vaginae distinctae, incolores, interdum paucim lamellosae. Trichomata cylindrica, ad dissepimenta non constricta, tantum rare constricta in paries meristematicis vel in hormogonia, ad apices rarissime dilatata, in media parte et basim interdum indistinte brevior; in partes superiores 5-6 $\mu \mathrm{m}$ latae, in partes attenuates ad 3 um latae. Cellulae aeruginosae, olivaceo-virides vel lutescentes, plus minusve isodiametricae, in partis meristematicis hormogoniisque brevior quam latae, in partes attenuates cylindricae, ad $2 \times$ longior quam latae; cellulae apicales late rotundatae, interdum pallide lutescentes. Heterocytae basales ovatae, breve barriliformes, hemisphericae ad rotundate cylindricae; heterocytae intercalares plus minusve cylindricae, 5-12 $\mu \mathrm{m}$ longae. - Habitatio: Subaerophytice ad rupes et in locis saxosis in silvis tropicalibus; locus classicus: ad Jureia, Brasilia (São Paulo). - Typus (holotypus): Exsiccatum SP 400883; dep. in herbarium (SP) Institute of Botany, SP, Brazil.

\section{Discussion}

The modern analyses of cyanobacterial microflora of not yet studied and not well known habitats in the biosphere, particularly with extreme conditions or in tropical areas, indicate that the number of various morpho- and ecotypes in such localities is more diversified, as was known from up to date investigations. This fact is supported from all molecular studies, which were realized up to now, especially from extreme biotopes (TATON et al. 2003; GUGGER et al. 2005; KOMÁreK et al. 2005; FIORE et al. 2007; TURRICCHIA et al. 2009; etc.). The recognition of not known cyanobacterial types from aerophytic habitats in tropical rainy forests is therefore not surprising and description of many new generic units is expectable.

The modern taxonomy of cyanobacteria 


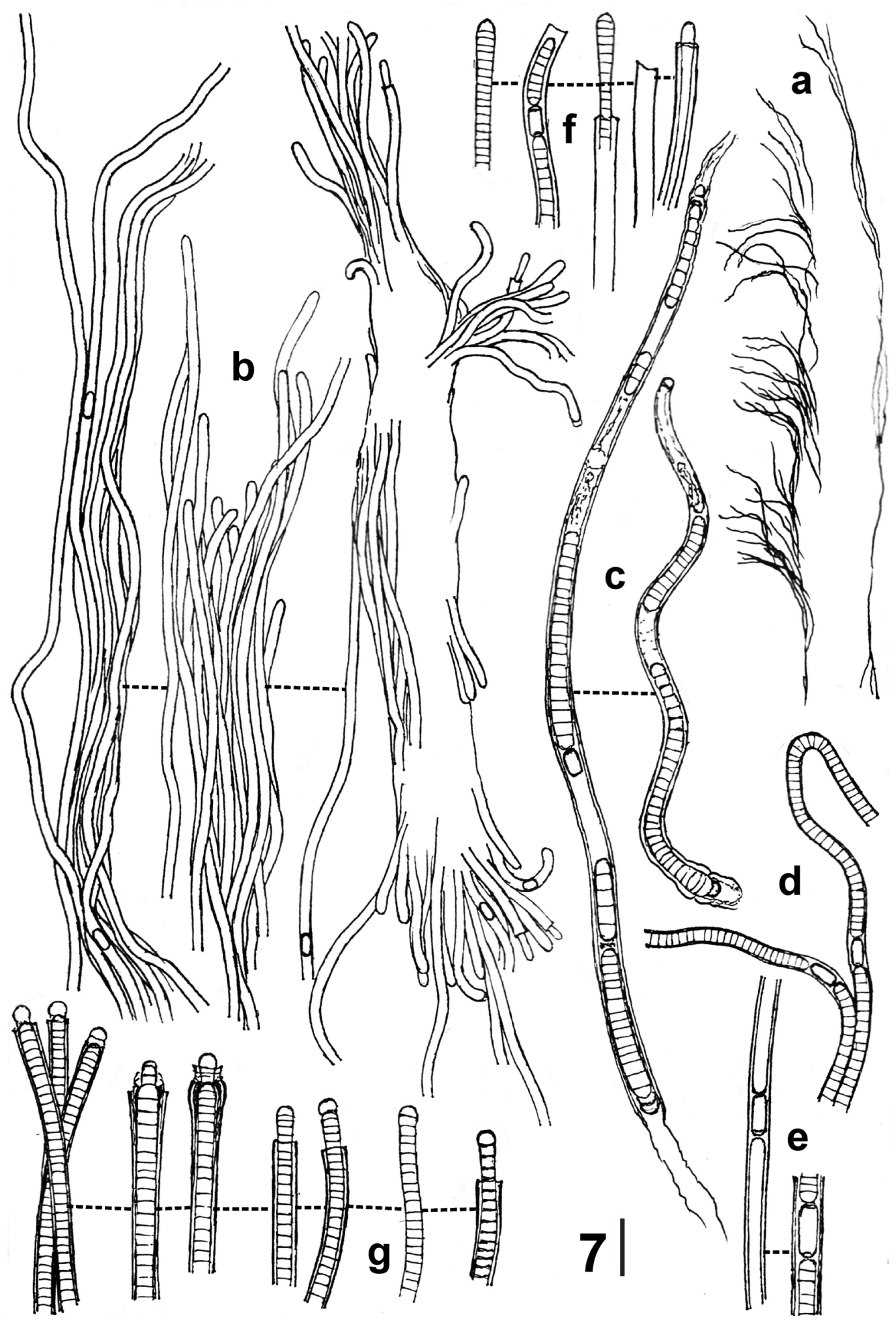

Fig. 7. Streptostemon capitatus sp. nov. (orig.): (a) colony at low magnification; (b) arrangement of filaments in colonies; (c) young trichomes; (d) trichomes from the end of a colony; (e) morphology of intercalar heterocytes; (f) morphology of terminal parts of young filaments; (g) terminal parts of old filaments. Scale bar $20 \mu \mathrm{m}$. 
is revised preferentially by molecular methods, especially by sequencing of $16 \mathrm{~S}$ rRNA. The phylogenetic support is required also in all new described cyanobacterial units, particularly on generic level. Numerous microchaetacean genera were already supported by genetic markers, e.g. by FleChTNer et al. (2002: Spirirestis, Tolypothrix, Coleodesmium), CASAMatTa et al. (2006: Rexia), Hauer (in litt.: Tolypothrix, Hassallia), and others. It is important, that all revised genera have quite special and characteristic, autapomorphic morphological markers. If we found, therefore, special types of cyanobacteria, the phenotypic habitus of which is evidently quite unique and can not be classified to any known genus, the establishment of new genera is justifiable. It is also the case of Ophiothrix and Streptostemon. The cultivation of such cyanobacteria from specialized biotopes and from rich communities of other algae and cyanobacteria is usually complicated and the separation and concentration of material for molecular treatment is a problem for a long time. In spite of it, we consider the description of such new discovered types as desirable for future research (Table 2).

Both new described genera are classified into the family Microchaetaceae (which includes also the genus Tolypothrix), separated from the morphologically most related family Scytonemataceae. The differences or respective identity of Tolypothrix with Scytonema were commonly discussed in the past, but usually only the character of type of branching (solitary or geminate branches) was taken in consideration. However, recent molecular analyses, in which the differences between both these genera were also evaluated, indicate the distinct separation of both types. The polarity of filaments and hormogonia, type of germination of hormogonia, prevailing type of branching and a role of heterocytes in the branching process are the main phenotypic markers of microchaetacean and scytonematacean genera. The diversity of the cluster of Scytonemataceae (containing genera Scytonema, Petalonema and Brasilonema) follows from different recent papers (comp. e.g., Fiore et al. 2007). The molecular evaluation of both families Microchaetaceae and Scytonemataceae needs still further studies, but it is not a problematic solved in this article. We have select, therefore, the phylogenetic tree from FLECHTNER et al. (2002) as the most illustrative for the delimitation of the microchaetacean family, into which our new genera must be classified according to all phenotypic features (Fig. 1).

In the case of our new types, the genus Ophiothrix appeared already sporadically in floristic literature concerning similar tropical regions and habitats (SCHMIDLE 1900a, 1900b; Duvigneaud \& Symoens 1949; KomÁreK 2003). However, the old authors considered these types as members of Scytonema or Camptylonemopsis, the young stages of which are morphologically more or less similar to Ophiothrix. KOMÁReK (2003) described according to natural observation the life cycle of "Camptylonemopsis", which is based on the combination of life cycles of Brazilian species "Camptylonemopsis" $=($ Ophiothrix $)$ epibryos and "Camptylonemopsis" $=($ Brasilonema $)$ sennae . The first part of this cycle corresponds morphologically more or less to Ophiothrix, the second evidently to the initial stages of Brasilonema sennae. The genus Camptylonemopsis, originally described from India, contains evidently only the creeping types with narrowed central part of trichomes and has other type of vegetative cells. On the other hand, we did not found in literature any data about the genus Streptostemon, which seems to be a very special morphotype, known up to now only from aerophytic soils and rocky habitats in Mata Atlântica.

\section{Acknowledgement}

The study was supported by the Brazilian grant CNPq 308086/2004-0 and by the Czech grants IAA6000050704 and GA CR 206/08/0318.

\section{References}

Bourrelly, P. (1970): Les algues d'eau douce. III. 512 pp., N. Boubée \& Cie., Paris.

Casamatta, D.A., Gomez, S.R. \& Johansen, J.R. (2006): Rexia erecta gen. et sp. nov. and Capsosira lowei sp. nov., two newly described cyanobacterial taxa from the Great Smoky Mountains National Park (USA). - Hydrobiologia 561: 13-26.

Castenholz, R.W. (2001): Oxygenic photosynthetic bacteria. - In: Boone, D.R. \& CAstenholz, R.W. (eds): Bergey's Manual of Systematic Bacteriology (2nd edition). - pp. 473-600, Springer-Verlag, New York.

Duvigneaud, P. \& Symoens, J.J. (1949): Observations sur la strate algale des formations herbeuses du Sud du Congo Belge. - Lejeunia 13: 67-98.

Fiore, M.F., Sant'Anna, C.L., Azevedo, M.T.P., Komárek, J., Kaštovský, J., Sulek, J. \& LorEnzI, A.S. (2007): The cyanobacterial 


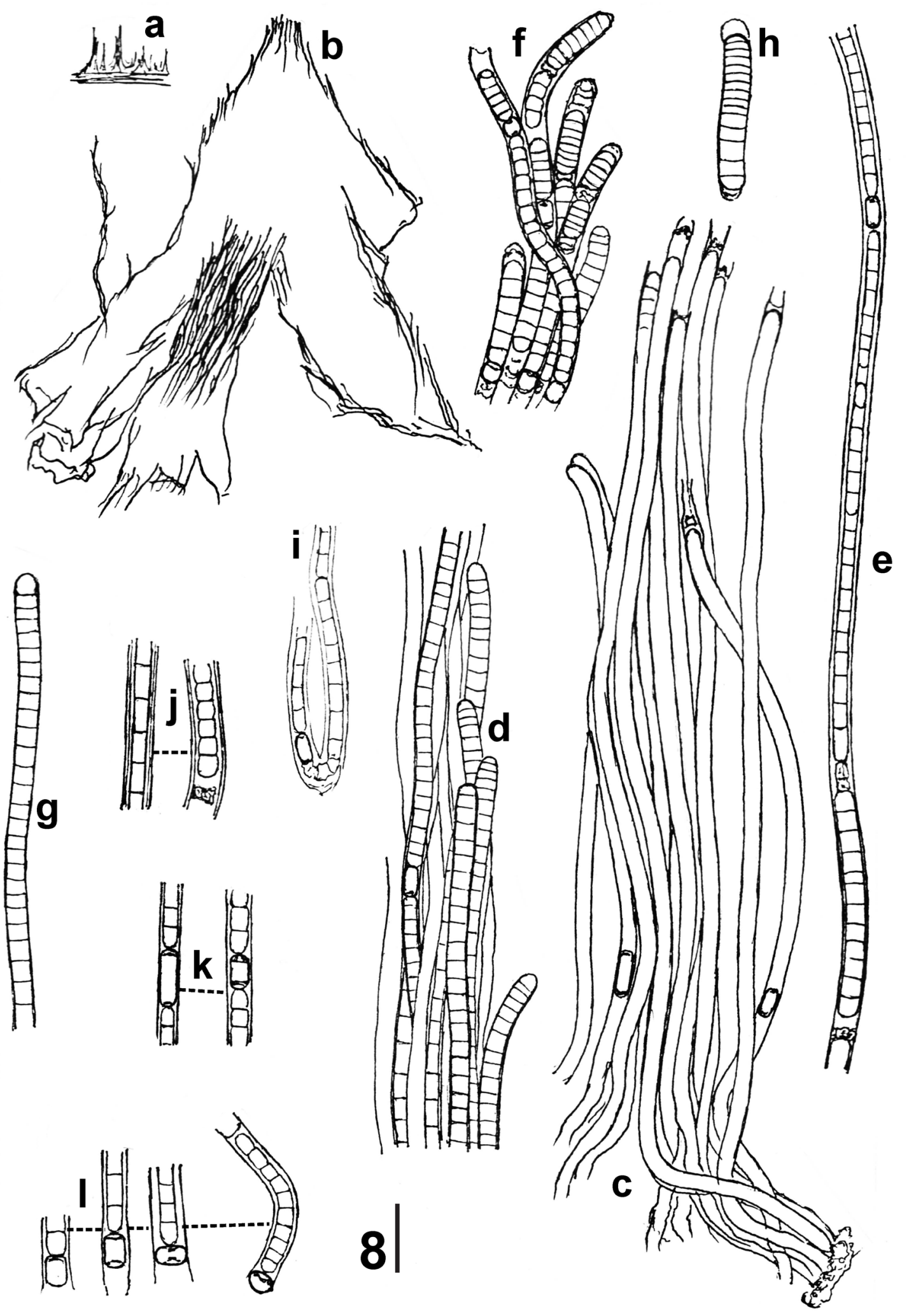

Fig. 8. Streptostemon lutescens sp. nov. (orig.): (a-b) form of colonies at different magnifications; (c-d) arrangement of filaments in colonies; (e) detail of one filament; (f) group of germinating hormogonia; (g) terminal part of a young trichome; (h) germinating hormogonium; (i) part of a bent filament from a colony; (j) detail of cells; (k) variability of intercalar heterocytes; (1) details of bases of filaments in a colony. Scale bar $20 \mu \mathrm{m}$. 
genus Brasilonema - molecular and phenotype evaluation. - J. Phycol. 43: 789-798.

Flechtner, V. R.; Boyer, S.L.; Johansen, J.R. \& DeNoble, M.L. (2002): Spirirestis rafaelensis gen. et sp. nov. (Cyanophyceae), a new cyanobacterial genus from arid soils. - Nova Hedwigia 74: 1-24.

Geitler, L. (1932): Cyanophyceae. - In: Rabenhorst's Kryptogamenflora, 14. - 1196 pp., Akad. Verlagsges., Leipzig.

Geitler, L. (1942): Schizophyta: Klasse Schizophyceae. - In: Engler A. \& Prantl K. (eds): Die Natürl. Pflanzenfamilien 1b. - 232 pp., Leipzig.

Greuter W., McNeil J., Barrie F.R., Burdet H.-M., Demoulin V., Filguiras T.S., Nicholson D.H., Silva P.c., Skog J.E., Trehane P., Turland N.J. \& Hawksworth D.L. (2000): International Code of Botanical. - Regnum Vegetabile, 138: 1-474.

Gugger, M., Molica, R., Le Berre, B., Dufour, P., Bernard, C. \& Humbert, J.-F. (2005): Genetic diversity of Cylindrospermopsis strains (Cyanobacteria) isolated from four continents. - Appl. Environm. Microbiol. 71: 1097-1100.

Hoffmann, L., KomÁreK, J. \& KaštovskÝ, J. (2005): System of cyanoprokaryotes (cyanobacteria) - state in 2004. - Algological Studies 117 (Cyanobacterial Research 6): 95-115.

KomÁrek, J. (2003): Two Camptylonemopsis species (Cyanoprokaryotes) from "Mata Atlântica" in coastal Brazil. - Preslia 75: 223-232.
KomáreK, J. \& Anagnostidis, K. (1989): Modern approach to the classification system of Cyanophytes 4 - Nostocales. - Algological Studies 56: 247-345.

Komárek, J., Ventura, S., Turicchia, S., Komárková, J., Mascalchi, C. \& Soldati, E. (2005): Cyanobacterial diversity in alkaline marshes of northern Belize (Central America). Algological Studies 117 (Cyanobacterial Research 6): 265-278.

Schmidle, W. (1900a): Algologische Notizen IV. Einige neue von Prof. Dr. Hansgirg in Vorderindien gesammelte Süswasseralgen. - Allg. Bot. Ztschr. 6: 17-19, 33-35, 54-55, 77-79.

Schmidle, W. (1900b): Ueber einige von Professor Hansgirg in Östindien gesammelte Süswasseralgen. - Hedwigia 39: 160-190.

Taton, A., Grubisic, S., Brambilla, E., De Wit, R. \& Wilmotte, A. (2003): Cyanobacterial diversity in natural and artificial microbial mats of Lake Fryxell (McMurdo Dry Valleys, Antarctica): a morphological and molecular approch. - Appl. Environm. Microbiol. 69: 5157-5169.

Turicchia, S., Ventura, S., KomÁrková, J. \& KomÁrek, J. (2009): Taxonomic evaluation of cyanobacterial microflora from alkaline marshes of northern Belize. 2. Molecular and phenotype diversity of oscillatorialean genera. - Nova Hedwigia 89: 165-200.

(C) Czech Phycological Society

Received February 3, 2010

Accepted April 7, 2010 